\title{
HUBUNGAN PENERAPAN ISO 9001:2000 DAN ORGANISASI BELAJAR TERHADAP KINERJA STAF
}

\author{
Elais Retnowati* \\ Sutaryat Trisnamansyah**
}

\begin{abstract}
The objective of this research is to analyze the relationship of ISO 9001:2000 implementation with the learning organization and the staff performance in an institution. This study is conducted in P2PNFI Region I Jayagiri and P2PNFI Region II Semarang. The design of development strategies on this research are: (1) conducting the beginning study; (2) creating research instruments; (3) testing instruments; (4) analyzing the validity and reliability instruments; (5) distributing questioners to 94 respondents at P2PNFI Regional I Jayagiri and 84 respondents at P2PNFI Regional II Semarang; (6) collecting questioners; (7) data input and processing; (8) conducting data analyzing and (9) wrapping up the conclusion. The research reveals that (1) there is an increase of the staff performance; (2) a positive correlation between the implementation of ISO 9001:2000 with the staff performance; (3) a positive relationship between the learning organization with the staff performance and (4) a correlation between the implementation of ISO9001:2000 with the performance of staff at two institutions.
\end{abstract}

Keywords : ISO 9001 : 2000, learning organization, staff performance, systems thinking, personal mastery, mental model, shared vision, team learning

\begin{abstract}
Abstrak
Penelitian ini bertujuan untuk mengetahui hubungan penerapan ISO 9001:2000 dengan organisasi pembelajar dan kinerja staff di suatu lembaga. Penelitian ini dilakukan di Lembaga P2PNFI Regional I Regional I Jayagiri dan P2PNFI Regional II Semarang. Strategi pengembangan disain penelitian adalah dengan : (1) studi pendahuluan, (2) menyusun intrumen penelitian, (3) uji coba intrumen, (3) melakukan analisa validitas dan reliabilitas instrumen, (4) menyebarkan angket kepada responden 94 orang responden di P2PNFI Regional I Jayagiri dan 84 orang responden di P2PNFI Regional II Semarang, (5) mengumpulkan angket, (6) mengolah data, (7) melakukan analisa data terhadap kedua kelompok responden penelitian, serta (8) penarikan kesimpulan atas kedua kelompok penelitian. Hasil penelitian menunjukkan bahwa terdapat : (1) adanya peningkatan kinerja staf, (2) adanya hubungan antara penerapan ISO 9001:2000 dengan kinerja staf, (3) adanya hubungan antara organisasi pembelajar dengan kinerja staf dan (4) adanya hubungan antara penerapan ISO 9001:2000 dan organisasi pembelajar dengan kinerja staf di kedua kelompok penelitian.
\end{abstract}

Kata-kata Kunci: ISO 9001:2000, organisasi belajar, kinerja pegawai, berpikir sistem, penguasaan perorangan, mental model, visi bersama, belajar beregu

\section{PENDAHULUAN}

\section{Latar Belakang}

Negara Republik Indonesia sebagai negara yang merdeka, berdaulat, dan bebas dari penjajahan memiliki tujuan seperti yang tertulis pada pembukaan Undang-Undang Dasar (UUD) Negara Republik Indonesia Tahun 1945 yaitu mencerdaskan kehidu-

* Dosen PLS FIP UNJ

** Dosen PLS UPI pan bangsa. UUD 1945 mengamanatkan mengenai pentingnya pendidikan bagi seluruh warga negara sebagaimana diatur dalam Pasal 28 C Ayat (1) bahwa setiap orang berhak mengembang-kan diri melalui pemenuhan kebutuhan dasarnya, berhak mendapatkan pendidikan dan memperoleh manfaat dari ilmu pengetahuan dan teknologi, seni dan budaya demi 
meningkatkan kualitas hidupnya dan demi kesejah-teraan umat manusia, dan pasal 31 menjelaskan tanggung jawab pemerintah dalam menyelenggarakan pendidikan, bahwa (1) setiap warga negara berhak mendapatkan pendidikan; (2) setiap warga negara wajib mengikuti pendidikan dasar dan pemerintah wajib membiayainya; (3) pemerintah mengusahakan dan menyelenggarakan satu sistem pendidikan nasional yang meningkatkan keimanan dan ketakwaan serta akhlak mulia dalam rangka mencerdaskan kehidupan bangsa; (4) negara memprioritaskan anggaran pendidikan sekurang-kurangnya dua puluh persen dari anggaran pendapatan dan belanja negara serta dari anggaran pendapatan dan belanja daerah untuk memenuhi kebutuhan penyelenggaraan pendidikan nasional; serta (5) pemerintah memajukan ilmu pengetahuan dan teknologi dengan menjunjung tinggi nilainilai agama dan persatuan bangsa untuk kemajuan peradaban serta kesejahteraan umat manusia (Majelis Permusyawaratan Rakyat/ Sekretariat Jenderal, Naskah Undang-Undang Dasar Negara Republik Indonesia Tahun 1945, 2008: 24).

Undang-Undang Nomor 20 Tahun 2003 tentang Sistem Pendidikan Nasional menyatakan bahwa pendidikan nasional berfungsi mengembangkan kemampuan dan membentuk watak serta peradaban bangsa yang bermartabat dalam rangka mencerdaskan kehidupan bangsa, bertujuan untuk berkembangnya potensi peserta didik agar menjadi manusia yang beriman dan bertakwa kepada Tuhan Yang Maha Esa, berakhlak mulia, sehat, berilmu, cakap, kreatif, mandiri, dan menjadi warga negara yang demokratis serta bertanggung jawab.

Pemerintah dan pemerintah daerah dituntut untuk mewujudkan fungsi dan tujuan tersebut, oleh karena itu, sebagai penyelenggara pendidikan berhak mengarahkan, membimbing, membantu, dan mengawasi penyelenggaraan pendidikan sesuai dengan peraturan perundang-undangan yang berlaku. Undang-undang dan peraturan tersebut sesuai dengan prinsip-prinsip dalam penyelenggaraan pendidikan nasional yang tercakup dalam Rencana Strategis Depdiknas (2005: 4-5), yaitu (1) demokratis dan berkeadilan serta tidak diskriminatif dengan menjunjung tinggi hak asasi manusia, nilai keagamaan, nilai kultural, dan kemaje-mukan bangsa; (2) satu kesatuan yang sistemik dengan sistem terbuka dan multimakna, diselenggara-kan sebagai suatu proses pembudayaan dan pember-dayaan peserta didik yang berlangsung sepanjang hayat; (3) memberi keteladanan, membangun kemauan, dan mengembangkan kreativitas peserta didik dalam proses pembelajaran;
(4) mengembangkan budaya membaca, menulis, dan berhitung bagi segenap warga masyarakat; dan (5) pendidikan diselenggarakan dengan memberdayakan semua komponen masyarakat melalui peran serta dalam penyelenggaraan dan pengendalian mutu layanan pendidikan.

Renstra Depdiknas Tahun 2005-2009 dalam rangka komitmen global diarahkan guna mempercepat sasaran Konvensi Hak-Hak Anak (Convention on The Rights of the Child) yang menyatakan: "Setiap negara di dunia melindungi dan melaksanakan hak-hak anak tentang pendidikan dengan mewujudkan wajib belajar pendidikan dasar bagi semua secara bebas" (Artikel 28) dan konvensi mengenai hak azasi manusia (HAM) yang menyatakan: "Setiap orang berhak atas pendidikan. Pendidikan harus bebas biaya, setidaknya pada pendidikan dasar (Dikdas). Pendidikan dasar harus bersifat wajib. Pendidikan teknik dan profesi harus tersedia secara umum dan pendidikan yang lebih tinggi harus sama-sama dapat dimasuki semua orang berdasarkan kemampuan" (Deklarasi HAM, Artikel 26). Hal ini sejalan dengan pencapaian sasaran pembangu-nan yang disepakati dalam Kerangka Aksi Dakar mengenai Pendidikan Untuk Semua (PUS) atau Education for All (EFA).

Upaya yang dilakukan oleh pemerintah dalam memenuhi komitmen internasional di bidang pendidikan adalah dengan melakukan perbaikan indikator kinerja Pendidikan Untuk Semua (PUS), dengan menekankan pada peran masyarakat dan pemerintah dalam pengelo-laan dan penyelenggaraan pendidikan. Pemerintah berusaha untuk menjalankan misi perluasan akses ini, program yang dilakukan adalah menyelenggarakan pendidikan formal dan nonformal yang bertujuan memberikan layanan pendidikan seluas-luasnya bagi masyarakat. Pendidikan formal diperuntukkan bagi masyarakat yang dapat mengakses pendidikan, sedangkan pendidikan nonformal ditujukan kepada masyarakat yang tidak terlayani dan tidak dapat mengakses pendidikan nonformal. Program-program pendidikan nonformal yang diperuntukkan kepada masyarakat antara lain 1) pendidikan keaksaraan, 2) pendidikan kesetaraan, 3) kursus-kursus, 4) pelatihan, dan 5) pendidikan anak usia dini (UU. No. 20 Tahun 2003, Pasal 26 ayat 3 )

Program pendidikan nonformal yang diselengga-rakan harus dapat meningkatkan daya saing agar masyarakat yang tidak dapat mengakses pendidikan tersebut dapat meningkatkan kualitas hidupnya. Tuntutan meningkatkan daya saing bagi penyelenggara pendidikan nonformal ini sesuai dengan tujuan pendidikan nasional butir 6 yaitu: “ ... Meningkatkan daya saing 
bangsa dengan menghasilkan lulusan yang mandiri, bermutu, terampil, ahli dan profesional, mampu belajar sepanjang hayat, serta memiliki kecakapan hidup yang dapat membantu dirinya dalam menghadapi berbagai tantangan dan perubahan ... ".

Tuntutan daya saing ini, berimplikasi kepada penyelenggara program pendidikan nonformal, agar program pendidikan yang dilaksanakan memiliki standar mutu yang telah ditentukan. Program pendidikan yang bermutu dapat diperoleh melalui proses penelitian dan pengembangan, proses ini dapat dilakukan secara internal oleh penyelenggara pendidikan atau masyarakat ataupun secara eksternal dari lembaga yang ditunjuk pemerintah untuk melakukan penelitian dan pengembangan mutu pendidikan nonformal yaitu Balai Pengembangan Pendidikan Nonformal-Informal (BPPNFI).

Tahun 2007, BPPPNFI berdasarkan Surat Keputusan Menteri Pendidikan Nasional Republik Indonesia berubah menjadi Pusat Pengembangan Pendidikan NonFormal dan Informal (P2-PNFI) Regional I Jayagiri. BPPNFI Regional II Semarang berdasarkan Surat Keputusan Menteri Pendidikan Nasional Republik Indonesia Nomor : 08/2008 tanggal 31 Maret 2008 berubah menjadi P2PNFI Regional II Semarang. P2PNFI mempunyai tugas melaksanakan perumusan kebijakan teknis, pengkajian dan pengembangan model pendidikan nonformal dan informal, serta memfasilitasi pengembangan sumber daya di bidang pendidikan nonformal dan informal di wilayah kerjanya.

P2PNFI juga bertugas untuk melaksanakan visi pendidikan nasional khususnya butir 2 dan 3 yaitu “... peningkatan mutu, relevansi, dan daya saing keluaran pendidikan, dan peningkatan tata kelola, akuntabilitas, dan citra publik pengelolaan pendidikan. Wujud dari pelaksanaan visi tersebut, maka P2PNFI harus memiliki sertifikasi standar mutu pelayanan yang dimaksud di sini adalah ISO 9001.

ISO 9001:2000 - merupakan Quality Management Systems - Requirements atau kualitas manajemen layanan ditujukan untuk digunakan di organisasi manapun yang merancang, membangun, memproduksi, memasang dan / atau melayani produk apapun atau memberikan bentuk jasa apapun. Standar ini memberikan sejumlah persyaratan yang harus dipenuhi oleh sebuah organisasi apabila hendak mem-peroleh kepuasan pelanggan sebagai hasil dari barang dan jasa yang secara konsisten memenuhi permintaan pelanggan tersebut.

Berubah atau melakukan perubahan dalam prosesnya terjadi suatu aktivitas yang disebut belajar (learning). Aktivitas belajar ini ada yang disadari atau tidak disadari. Apa yang dipelajari adalah segala sesuatu yang terjadi dalam perubahan itu sendiri baik yang terjadi karena dorongan lingkungan maupun karena diinginkan. Dalam suatu lembaga (P2PNFI), perubahan itu bisa terjadi karena adanya faktor tuntutan dari para konsumen setianya ataupun karena faktor lingkungan yang terus melakukan perubahan agar dapat memenuhi tuntutan tugas dan fungsi dari didirikannya lembaga tersebut. Oleh karenanya, semua lembaga harus selalu belajar terus menerus (continuing education) sepanjang lembaga itu ingin memper-tahankan keberadaannya. Suatu lembaga yang belajar disebut dengan Learning Organization (organisasi pembelajar). Hal ini terjadi karena selain sebagai tempat yang menghasilkan karya-karya unggulan (pilot project), model pembelajaran dan media pembelajaran, para staf, tenaga fungsional (pamong) juga dituntut untuk menghasilkan modul-modul pembelajaran.

Bentuk perubahan ini dipilih oleh P2PNFI karena lembaga ini perlu untuk memperhatikan trend tuntutan yang akan terjadi di masa depan yaitu produk yang memenuhi kepuasan pelanggan. Untuk itu, lembaga perlu menyiapkan organisasinya dalam menghadapi tantangan tersebut. Upaya-upaya yang dilakukan ditataran pucuk pimpinan manajemen diimbangi dengan melakukan pembelajaran (organisasi pembelajar) dari para tenaga fungsional dan staf P2PNFI sehingga terjadi proses belajar berkelanjutan (continuing education), belajar sepanjang hayat (lifelong education). Organisasi pembelajar oleh Senge (1990: 3) diartikan sebagai : “...organizations where people continually expand their capacity to create the results they truly desire, where new and expansive patterns of thinking are nurtured, where collective aspiration is set free, and where people are continually learning to see the whole together."

Proses organisasi pembelajar dapat terjadi jika dalam lembaga tersebut orang-orangnya terus meningkatkan kapasitas dirinya untuk menghasilkan sesuatu yang benar-benar dipilih atau diinginkan, di mana sesuatu yang baru dan cara berpikir ekspansi adalah alamiah datang dari orang-orang tersebut, bebas menentukan aspirasinya secara kolektif, dan orang-orang secara berkelanjutan belajar untuk melihat seluruhnya secara bersama-sama. Kewajiban lembaga adalah mencari cara atau menciptakan suasana untuk melakukannya. Cara atau pendekatan ini dalam pendidikan nonformal disebut sebagai belajar secara terus menerus atau belajar sepanjang hayat (lifelong learning).

Belajar sepanjang hayat dijelaskan dalam, 
General Conference of UNESCO (Cross, KP, 1981: 249) meliputi tiga hal yaitu "... restructuring at the existing system of education, the full development of all education potential outside the formal system, and the development of self directed learner, ... ". Dari pen-jelasan UNESCO ini, belajar sepanjang hayat terjadi untuk memperbaiki sistem pendidikan yang ada, mengembangkan seluruh potensi pendidikan di luar sistem pendidikan formal dan mengembangkan kemampuan untuk belajar sendiri. Tujuan utama pendidikan sepanjang hayat ini adalah untuk belajar mendalami keterampilan dasar dan motivasi untuk mempelajari berbagai macam aspek kehidupanya.

Belajar sepanjang hayat dalam tempat kerja merupakan tuntutan dasar bagi setiap individu atau orang dewasa agar dapat mengembangkan diri untuk memenuhi standar sumber daya manusia yang ditentukan dan dibutuhkan oleh lembaga tersebut (P2PNFI). Pentingnya belajar secara terus-menerus yang dilakukan oleh individu atau staf di tempat kerja merupakan tuntutan dari penerapan ISO yang difokuskan untuk memenuhi kepuasan layanan bagi pelanggan. Selain itu, masyarakat juga semakin haus dengan pendidikan, kemajuan ilmu pengetahuan dan teknologi. Oleh karena itu, lembaga harus terus mene-rus belajar dan berbenah diri, agar selalu terjadi transformasi dari lembaga yang klasik menjadi lembaga yang dapat memenuhi tuntutan pasarnya (costumer driven).

Staf atau pengelola lembaga dituntut untuk melaksanakan klausul-klausul dan menerapkannya di dalam pekerjaan sehari-hari membuat seluruh tenaga fungsional dan staf P2PNFI menjadi organisasi pembelajar. Sistem kerja berdasarkan ISO merupakan sistem kerja secara kelompok (group). Hasil kerja seseorang merupakan bagian dari kerja kelompok (working group).

Lembaga P2PNFI telah menjalankan manajemen kerja berdasarkan ISO 9001:2000 selama tiga tahun. Sejak diterapkan sampai saat ini diharapkan sudah terjadi suatu proses kerja yang baik berdasarkan ISO 9001:2000 karena telah terjadi suatu proses organisasi pembelajar atau belajar berkesinambun- gan sebagai upaya mewujudkan komitmen terhadap keputusan lembaga dalam penerapan ISO 9001:2000 sebagai tolok ukur kualitas layanannya kepada masyarakat. Untuk itu, perlu dilakukan suatu penelitian di kedua lembaga P2PNFI sebagai suatu lembaga pusat pengembang program pendidikan nonformal dan informal yang menggunakan manajemen ISO 9001:2000. Apakah di lembaga ini ISO 9001:2000 sudah dapat diimplementasikan dengan baik dan bagaimana organisasi pembelajar yang terjadi di kedua lembaga. Bila penerapan ISO 9001:2000 dan organisasi pem-belajar dapat terwujud bagaimana kinerja staf sebagai dampak dari adanya penerapan ISO 9001:2000 dan organisasi pembelajar. Setelah tiga tahun bila tidak dilakukan suatu penelitian terhadap pelaksanaan penerapan ISO 9001:2000, organisasi pembelajar serta kinerja staf di lembaga tersebut maka tidak akan diperoleh informasi apakah pelaksanaan penerapan ISO 9001:2000 dapat berjalan dengan baik, juga tidak diketahui apakah terjadi suatu pembelajaran terus menerus (life long learning). Organisasi yang berbasis pembelajaran lebin berfokus pada upaya melakukan pekerjaan dengan lebih baik dan memandang pembelajaran sebagai cara terbaik untuk meningkatkan kinerja jangka panjang.

\section{Rumusan Masalah}

Rumusan masalah dalam penelitian ini, adalah sebagai berikut.

1. Apakah ada hubungan antara penerapan ISO 9001:2000 dengan peningkatan kinerja staf di Lembaga P2PNFI Regional I Jayagiri dan Regional II Semarang?

2. Apakah ada hubungan antara organisasi pembelajar dengan peningkatan kinerja staf di Lembaga P2PNFI Regional I Jayagiri dan Regional II Semarang?

3. Apakah ada hubungan antara penerapan ISO 9001:2000 dan organisasi pembelajar dengan peningkatan kinerja staf di Lembaga P2PNFI Regional I Jayagiri dan Regional II Semarang ?

4. Apakah ada peningkatan kinerja staf di Lembaga P2PNFI Regional I Jayagiri dan Regional II Semarang?

\section{KAJIAN TEORETIS}

\section{Konsep ISO 9000}

Definisi dari Standar ISO 9000 untuk sistem manajemen kualitas (Quality Management System, QMS) adalah "struktur organisasi, tanggung jawab, prosedur-prosedur, proses-proses, dan sumber-sumber daya untuk penerapan manajemen kualitas". Suatu sistem manajemen kualitas (QMS) merupakan sekum- pulan prosedur terdokumentasi dan praktik-praktik standar untuk manajemen sistem yang bertujuan menjamin kesesuaian dari suatu proses dan produk (barang dan/atau jasa) terhadap kebutuhan atau persyaratan tertentu. Kebutuhan atau persyaratan itu ditentukan atau dispesifikasikan oleh pelanggan dan organisasi. Berkaitan dengan jenis pelanggan sendiri, 
menurut Gaspersz (1997; 34), terdapat tiga macam pelanggan yaitu "a. pelanggan internal, b. pelanggan antara, dan c. pelanggan ekternal."

Setiap lingkungan, pelaksanaan proses yang konsisten merupakan kunci untuk peningkatan terus-menerus yang efektif agar selalu memberikan produk (barang dan/atau jasa) yang memenuhi kebutuhan pelanggan. Pelanggan dalam konteks penelitian ini adalah masyarakat (individu atau kelompok) dan lembaga yang membutuhkan layanan pendidikan nonformal dan informal.

\section{Prinsip-Prinsip Pencapaian Layanan Standar ISO 9001:2000}

Manajemen kualitas ISO 9001 menurut Tricker (2001: 59 -122) dalam penerapannya mempersyaratkan delapan standar, yang terdiri dari (1) lingkup, (2) acuan yang mengatur, (3) istilah dan definisi, (4) sistem manajemen mutu, (5) tanggung jawab manajemen, (6) manajemen sumber daya, (7) realisasi produk, serta (8) pengukuran, analisis, dan peningkatan.

Sistem manajemen kualitas ISO 9001: 2000 (Gaspersz, 2006 : 75) disusun berdasarkan delapan prinsip manajemen kualitas. Delapan prinsip mana-jemen kualitas tersebut nantinya akan berintegrasi pada klausul-klausul ISO 9001: 2000. Delapan prinsip yang menjadi landasan penyusunan ISO 9001: 2000 adalah prinsip 1 : fokus pelanggan, prinsip 2 : kepemimpinan, prinsip 3 : keterlibatan orang, prinsip 4 : pendekatan proses, prinsip 5 : pendekatan sistem terhadap mana-jemen, prinsip 6 : peningkatan terus menerus, prinsip 7 : pendekatan faktual dalam pembuatan keputusan, prinsip 8 : hubungan pemasok yang saling menguntung-kan.

\section{Organisasi Pembelajar}

Organisasi yang belajar (organisasi pembelajar) dilandasi oleh penelitian yang dilakukan oleh Senge (1990: 3) yang memperkenalkan perlunya perubahan di dalam suatu organisasi atau lembaga. Senge menggambarkan organisasi pembelajar sebagai: “... organizations where people continually expand their capacity to create the results they truly desire, where new and expansive patterns of thinking are nurtured, where collective aspiration is set free, and where people are continually learning to see the whole together".

Definisi Senge tersebut menggambarkan organisasi pembelajar sebagai organisasi dengan orang-orang yang secara terus-menerus memperluas kapasitasnya untuk menciptakan hasil yang sungguh-sungguh diinginkan, yang menumbuhkan pola pikir baru dan ekspansif dan yang membiarkan aspirasi kolektif secara bebas, serta orang-orang yang secara terus-menerus berupaya belajar bersama.
Marquardt (1994: 22) mendefinisikan organisasi pembelajar (learning organization) sebagai berikut “... as a group of empowered employees who generate new knowledge, products, and services; network in an innovative community inside and outside the organization; and work toward a higher purpose of service and enlightment to the larger word".

Definisi Marquardt menggambarkan organisasi pembelajar sebagai suatu lembaga yang orang-orangnya belajar bersama dengan penuh semangat, terus menerus mentrasformasikan dirinya dengan pengetahuan yang baru, produk dan layanan; kemitraan di dalam dan di luar komunitas lembaga, serta bekerja keras untuk mencapai tujuan yang maksimal.

Wick dan Lean (1995: 299) mendefinisikan organisasi pembelajar sebagai berikut "as one that continually improves by rapidly creating and refining the capabilities required for future success." Seseorang yang secara terus menerus meningkatkan diri melalui peningkatan kreativitas dan memperbaiki kapabilitas yang dibutuhkan untuk mencapai kesuksesan di masa yang akan datang.

Burgoyne (1994: 7) menekankan bahwa “...learning organization have to be able to adapt to their context and develop their people to match the context". Pendapat yang hampir sama tentang organisasi pembelajar dikemukakan oleh Garvin (1993: 78) sebagai berikut : "...one that is skilled at creating, acquiring, and transferring knowledge, and at modifying its behaviour to reflect new knowledge and insights". Definisi Wick dan Lean, Burgoyne serta Garvin menggambarkan suatu kemampuan dari seseorang, sekumpulan orang yang berada dalam suatu lembaga yang selalu melakukan kreativitas, mempelajari segala sesuatu sesuai dengan tuntutan situasi dan perubahan yang direfleksikan dalam bentuk perilaku belajar untuk kemudian menggunakan pengetahuan yang diperoleh dari pembelajaran sebagai bentuk suatu pengetahuan baru dari hasil pengembangan kemampuan yang digunakan untuk tujuan tertentu.

Senge (1991:3-42) seperti yang dikutip oleh De Cenzo dan Robbins (1999, 241) menguraikan perlunya lima disiplin (fifth discipline) dalam organisasi pembelajar, di mana disiplin ke lima merupakan kunci yang mendasari keempat disiplin yang lain, yaitu "... system thinking, personel mastery, mental model, shared vision, and team learning". Kelima karakterisitik ini dalam pelaksanaannya dapat diterjemahkan sebagai berikut “...people need to put aside their old ways of doing thinking (mental models), learn to be open with others (personal mastery), understand how their company really works (system thinking), for a 
plan everyone can agree on (shared vision), and then work together to achieve that vision (team learning)".

Kelima disiplin pembelajaran menurut Senge tersebut dapat diuraikan sebagai berikut, pertama, Disiplin Personal Mastery. Disiplin ini mendorong sebuah organisasi untuk terus-menerus belajar bagaimana menciptakan masa depannya yang hanya akan terben-tuk jika para anggota organisasi mau dan mampu terus belajar menjadikan dirinya sebagai seorang master di bidang ilmunya. Disiplin personal mastery terbentuk dicirikan oleh tumbuhnya keterampilan-keterampilan individual para anggota organisasi untuk melakukan kontemplasi (refleksi) diri; keterampilan untuk memahami akan kelebihan dan kelemahan kompetensi intelektual, emosional maupun sosial dirinya; serta keterampilan untuk melakukan revisi atas visi pribadi-nya, dan kemudian keterampilan untuk membangun kondisi kerja yang sesuai dengan keadaan organisasi-nya.

Kedua, Disiplin Berbagi Visi. Organisasi pembelajar membutuhkan visi bersama yang disepakati oleh seluruh anggota organisasinya. Visi bersama ini akan menjadi kompas dan sekaligus pemicu semangat dan komitmen untuk selalu bersama, sehingga menumbuhkan motivasi kepada para karyawan untuk belajar dan terus belajar meningkatkan kompetensinya. Keterampilan untuk menyesuaikan antara visi pribadi dengan visi organisasi serta keterampilan berbagi visi agar mencapai tujuan pribadi yang terkandung dalam visi bersama organisasi, merupakan disiplin individual yang dibutuhkan untuk membangun disiplin berbagi visi. Artinya, untuk menumbuhkan komitmen dan perfor-mansi yang tinggi dari seluruh karyawan, harus dimulai dari adanya visi bersama. Tanpa adanya visi bersama, proses pembelajaran organisasional hanya akan terjadi pada saat organisasi mengalami krisis. Setelah krisis lewat/usai, organisasi pembelajar akan kembali berhenti, dan sikap serta perilaku para anggota organisasi akan kembali kepada kebiasaan-kebiasaan lamanya.

Ketiga, Disiplin Berpikir Sistemik: Disiplin yang oleh Senge (1990) berfungsi untuk melengkapi disiplin bagaimana seseorang belajar, yaitu disiplin untuk memahami apa sebenarnya yang dipelajari. Kemam-puan untuk berpikir secara sistemik yaitu keterampilan untuk memahami struktur hubungan antara berbagai faktor internal maupun eksternal yang mempengaruhi eksistensi organisasi, keterampilan untuk berpikir integratif dan tuntas, keterampilan untuk berpikir komprehensif, serta keterampilan untuk membangun organisasi yang adaptif.

Keempat, Disiplin Mental Model. Mental model banyak berpengaruh pada cara bekerja seseorang. Mental model berasal dari Argyris dan kolega-keloganya di Harvard University. Mental model adalah salah satu cara untuk melihat dunia. Ini merupakan suatu framework bagi proses bepikir seseorang. Dengan kata lain, ini menentukan cara seseorang berpikir dan ber-tindak.

Kelima, Disiplin Pembelajaran Tim. Disiplin pembelajaran tim akan efektif jika para anggota kelompok tersebut memiliki rasa saling membutuhkan satu dengan yang lainnya untuk dapat bertindak sesuai dengan rencana bersama. Kemampuan untuk bertindak merupakan prasyarat untuk menciptakan nilai tambah oganisasi. Untuk itu, kemampuan untuk membangun ikatan emosional, semangat berdialog, keterampilan bekerjasama secara tim, kemampuan belajar dan beradaptasi, serta usaha untuk meningkatkan partisipasi merupakan disiplin yang dibutuhkan untuk membangun disiplin pembelajaran tim.

Menurut Senge (1990:236), suatu tim akan menjadi kunci dalam belajar di dalam unit organisasi, definisi team learning adalah : "...the process of aligning and developing the capacity of a team to create the results its members truly desire. It builds on the discipline of developing shared vision. It also builds on personal mastery, for talented teams are made up of talented individuals".

Organisasi pembelajar dalam lembaga P2PNFI terjadi karena diterapkannya standar mutu layanan ISO 9001:2000 yang merupakan suatu hal yang baru bagi lembaga tersebut. Dengan standar ini, maka P2PNFI melakukan perubahan dalam manajemen pelayanan-nya. Perubahan ini jika diterima dengan baik, maka seluruh staf P2PNFI akan berusaha melakukan suatu proses pembelajaran, belajar mengadaptasi standar layanan ISO 9001:2000 sebagai prosedur dalam bekerja. Proses organisasi pembelajar yang terjadi akan tampak dalam perilaku bekerja seluruh staf meliputi kelima disiplin pembelajaran yaitu (1) kemampuan pribadi (personal mastery), (2) berbagi visi (shared vision), (3) model mental (mental model) , (4) berpikir sistemik (system thinking), dan (5) belajar bersama (team learning).

\section{Belajar Sepanjang Hayat (Lifelong Learning)}

Belajar sepanjang hayat oleh Knapper \& Kropley (2000: 11) didefinisikan sebagai “... lifelong education has been defined as a set of organisational, administra-tive, methodological, and procedural measures ..."yang dapat diartikan bahwa pendidikan sepanjang hayat sebagai seperangkat organisasional, administratif, metodologi, dan prosedur-prosedur pengukuran... Sedangkan "... lifelong learning describes the habit 
of continuously learning throughout life, a mode of behavior". Belajar sepanjang hayat menggambarkan suatu kebiasaan belajar yang berkesinambungan dalam kehidupan merupakan suatu model perilaku. Belajar sepanjang hayat (lifelong learning) dan pendidikan sepanjang hayat (lifelong education) sering dimaknakan yang sama, namun sesungguhnya belajar sepanjang hayat dan pendidikan sepanjang hayat merupakan dua konsep. Kedua konsep itu saling mengisi dan tidak terpisahkan satu sama lain. Trisnamansyah (2007: 5) berpendapat bahwa pendidikan sepanjang hayat mengacu pada serangkaian faktor-faktor ekstrinsik, berorientasi penyediaan (suplay) dengan mengidentifi-kasi kebutuhan (the needs) dan penyediaan peralatan (the means). Sedangkan, belajar sepanjang hayat bersifat intrinsik, berorientasi permintaan dan sangat bergantung kepada motivasi dan kemampuan individu pembelajar. Di antara keduanya mesti ada keseim-bangan supaya terjadi peningkatan sinergi dan outcome yang produktif.

Ada banyak definisi yang diberikan untuk konsep belajar sepanjang hayat. Berikut ini adalah makna belajar sepanjang hayat yang didefinisikan oleh Longworth dan Davies : “..the development of human potential through a countiuously supportive process which stimulates and empowers individuals to acquire all the knowledge, values, skills and understanding they will require throughout their life times and to apply them with confidence, creativity and enjoyment in all roles, circumstances, and environments". (Longworth dan Davies, 1996: 22)

Definisi Longworth dan Davies ini melengkapi pengertian belajar sepanjang hayat yang dikemukakan sebelumnya bahwa belajar sepanjang hayat adalah upaya untuk mengembangkan potensi seseorang melalui suatu proses yang menstimulasi dan memper-luas kemampuan seseorang dalam memperoleh pengetahuan, nilai, keterampilan yang dibutuhkan selama kehidupan, melengkapinya dengan kreativitas, dan dapat menikmati semua peran yang diberikan oleh lingkungan. Belajar sepanjang hayat terjadi pada setiap saat dan pada setiap orang yang selalu berupaya meningkatkan kualitas dirinya untuk memenuhi kebutu-hannya dengan carayang dipilihnya sendiri.

Belajar sepanjang hayat tidak hanya terjadi pada seseorang individu namun juga terjadi dalam konteks organisasional. Organisasi dalam hal ini adalah wadah-nya, yang di dalamnya terdapat unsur manajemen, struktur dalam hal ini ada pemimpin dan yang dipimpin, sistem, sarana, dan ada konsumen atau orang yang diberi layanan oleh organisasi. Organisasi melakukan pembelajaran karena adanya perubahan-perubahan di antaranya : adanya perkembangan teknologi, peruba-han keinginan konsumen, adanya kompetisi dan sebagainya yang semua itu menuntut organisasi atau lembaga untuk melakukan perbaikan atau perubahan. Melakukan perbaikan atau perubahan agar dapat beradaptasi dengan tuntutan lingkungan merupakan proses belajar yang terus menerus (lifelong learning).

Belajar yang dilakukan oleh staf dan tenaga fungsional di BPPNFI dan P2PNFI Regional II sehubungan dengan penerapan manajemen pelayanan berstandar ISO: 9001 adalah belajar seperti yang dikemukakan oleh Longworth yaitu belajar untuk meningkatkan kemampuan dalam menjalankan tugas yaitu memberikan layanan sesuai dengan standar ISO; P2PNFI telah menjadi suatu lembaga yang menggunakan standar layanan taraf internasional; P2PNFI juga melakukan berbagai kemitraan dengan lembaga-lembaga lain sebagai pemasok maupun pemakai jasa layanan dan program yang dihasilkan oleh P2PNFI; mengembangkan suatu lembaga yang belajar melalui proses adaptasi terhadap suatu sistem kerja baru dengan memberdayakan orang-orangnya (empowers individuals) untuk belajar atau saling membelajarkan agar dapat melaksanakan tugas sesuai dengan yang telah distandarkan dalam manajemen berbasis ISO.

Organisasi Pembelajar dalam Perspektif Pembelajaran Sepanjang Hayat

Kebutuhan sumber daya manusia yang berkualitas dalam organisasi perlu didorong untuk memiliki kesadaran belajar secara terus-menerus atau (lifelong learning). Sebab hanya dengan belajar yang terus-menerus, organisasi tersebut dapat maju, pentingnya belajar sepanjang hayat ini, Lee A., (1997:303) bahwa: "... learning as the prime sub-componen, presupposes a process of self directed, through perhaps economically driven, exploration, and discovery of knowledge, skill, and abilities. ...".

Konsep organisasi pembelajar merupakan bagian dari pandangan konsep belajar sepanjang hayat, sebab aktivitas individu atau kelompok dalam sebuah organi-sasi dapat melakukan kegiatan pembelajaran melalui pembelajaran formal, nonformal, dan informal experiences seperti on the job training, learning by doing, and all other everyday forms of experience.

Pendidikan sepanjang hayat sebagaimana dikemukakan Dave (1982: 72) adalah "Education is viewed as a continuing process guided by the over-ridding goal of improving the quality of life". Pendidikan dipandang sebagai proses berkelanjutan yang dibim-bing oleh tujuan untuk meningkatkan kualitas hidup merupakan tuntutan yang harus dipenuhi oleh setiap individu atau masyarakat karena tugas 
dan tanggung jawab yang besar dalam menjalankan tugas-tugas di tempat kerja.

Bentuk-bentuk belajar sepanjang hayat yang di dalamnya terkandung unsur organisasi pembelajar adalah representasi tentang program-program Pendidikan Luar Sekolah yang dikenal selama ini adalah rangkaian dari perwujudan realitas pelaksanaan belajar sepanjang hayat (lifelong learning), wujud belajar sepanjang hayat tersebut adalah terjadinya proses dan kemauan individu atau masyarakat untuk mengikuti aktivitas-aktivitas pendidikan, yaitu proses pendidikan yang berlangsung sejak manusia dilahirkan ke dunia sampai akhir hayat, tidak terbatas individual atau kelompok masyarakat atau dalam pendidikan formal saja, akan tetapi dalam pendidikan di masyarakat atau di tempat kerja yang berlangsung secara berkelanjutan atau terus-menerus.

\section{Konsep Kinerja.}

Kinerja atau performance memiliki banyak pengertian bergantung pada sudut pandang orang yang mendefinisikannya. Wibowo (2009: 2) mendefinisikan kinerja sebagai "hasil kerja atau prestasi kerja". Sesungguhnya kinerja bermakna lebih luas tidak hanya sebagai hasil kerja tetapi juga tentang bagaimana suatu proses kerja berlangsung. Kinerja juga berkaitan dengan melakukan pekerjaan, apa yang dikerjakan, dan bagaimana melakukannya. Kinerja menurut Amstrong dan Baron (1998: 15) merupakan hasil pekerjaan yang mempunyai hubungan kuat dengan tujuan strategis organisasi, kepuasan konsumen, dan memberikan kontribusi ekonomi.

Sturman (2001:610) mengatakan kinerja adalah suatu konstruk multidimensional yang sangat kompleks, tergantung pada siapa yang mengevaluasi, bagaimana dievaluasi, dan aspek apa yang dievaluasi.

Rudman (1998: 2) mendefinisikan kinerja dengan "...Performance is what we need from employee for organizations to achieve their business objectives". Definisi Rudman terhadap kinerja mengandung makna bahwa kinerja merupakan wujud kemampuan kerja yang diinginkan suatu lembaga atau organisasi dari seorang pekerja untuk mencapai tujuan organisasi. Definisi Rudman sejalan dengan pendapat Moeheriono, kinerja oleh Moeheriono (2009:61) dikatakan bahwa: “... pada dasarnya berasal dari kata job performance atau disebut juga sebagai actual performance atau diartikan sebagai prestasi kerja yang secara aktual telah dicapai oleh seseorang karyawan". Menurut Oxford Dictionary, seperti yang dikutip oleh Moeheriono (2009: 61), kinerja (performance) merupakan suatu tindakan proses atau cara bertindak atau melakukan fungsi organisasi. Menurut The Scriber-Bantam Eng- lish Dictionary, seperti yang dikutip oleh Moeheriono (2009:61), kinerja berasal dari kata "...to perform" dengan beberapa entries, yaitu (1) melakukan, menjalankan, melaksanakan (to do or carry of a execute), (2) memenuhi atau melaksanakan kewajiban suatu niat (to discharge of fulfil; as vow), (3) melaksanakan atau menyempurnakan tanggung jawab (to excute or complete an understanding), (4) melaku-kan sesuatu yang diharapkan oleh seseorang atau mesin (to do what is expected of a person or machine).

Dari berbagai definisi tentang kinerja yang diajukan oleh beberapa ahli seperti yang tertulis di atas dapat disimpulkan bahwa kinerja adalah suatu hasil atau kondisi (prestasi) yang diperoleh sebagai hasil dari suatu tindakan yang dilakukan oleh seseorang atau sekelompok orang atas tugas-tugas yang menjadi tanggung jawabnya sesuai dengan tujuan yang ingin dicapai yang telah ditetapkan sebelumnya.

Selanjutnya, Moeheriono menyimpulkan bahwa kinerja merupakan hasil kerja yang dapat dicapai oleh seseorang atau sekelompok orang dalam suatu organisasi baik secara kuantitatif maupun kualitatif, sesuai dengan kewenangan dan tugas tanggung jawab masing-masing, dalam upaya mencapai tujuan organisasi bersangkutan secara legal, tidak melanggar hukum dan sesuai dengan moral maupun etika.

Seseorang agar memiliki kinerja tinggi secara maksimal seharusnya memiliki kompetensi yang sesuai dengan kompetensi yang dibutuhkan oleh jabatannya, dengan demikian, akan terjadi kesesuaian antara kompetensi individu dengan tugas yang diemban sehingga akan menghasilkan kinerja yang diharapkan. Kompetensi biasanya dihubungkan dengan nilai, standar, serta pandangan hidup seseorang yang merupakan dasar aspek kepribadian seseorang yang penting dalam mengerjakan tugas dan tanggung jawabnya. Kompetensi pada sektor bisnis dengan sektor publik ada perbedaannya. Pada sektor bisnis, kompetensi mencakup pada dua lingkup yaitu individu dan organisasi. Pada sektor publik saat ini konsep kompetensi lebih mengarah pada kompetensi untuk jabatan struktural, jabatan fungsional, maupun staf pelaksana. Kompetensi jabatan menurut Moeheriono (2009: 22-24), mencakup dua komponen dasar, yaitu (1) kompetensi utama dan (2) kompetensi pendukung.

Kompetensi utama merupakan kompetensi yang harus dimiliki seseorang berkaitan dengan suatu jabatan atau tugas pekerjaan pada lingkup tertentu. Kompetensi utama ini meliputi kemampuan-kemam-puan sebagai berikut (1) akuntabilitas, (2) organisasi pembelajar, (3) penentuan masalah dan pemecahannya, (4) manajemen perubahan, (5) perencanaan strategik, 
(6) manajemen kebijakan, (7) manajemen kinerja, (8) manajemen kualitas pelayanan, (9) manajemen kerja-sama. Kompetensi pendukung merupakan kompetensi yang diperlukan untuk membantu atau mendukung terwujudnya pelaksanaan jabatan tertentu, yang meliputi kemampuan-kemampuan sebagai berikut (1) komunikasi dan (2) teknologi informasi.

Kompetensi sumber daya manusia akan menghasilkan kinerja berhubungan dengan kedudukan masing-masing individu dalam organisasi tergantung pada tujuan organisasi tersebut. Tujuan organisasi yang jelas akan mempengaruhi pola kerja dan kinerja karyawan. Tujuan organisasi yang jelas bagi semua karyawan dapat dijadikan pedoman dalam meningkat-kan produktivitas kerja. Pada staf P2PNFI, bentuk kompetensi yang seharusnya dimiliki dalam bekerja adalah lebih mengarah pada kompetensi untuk jabatan struktural, jabatan fungsional, maupun staf pelaksana namun disesuaikan dengan tujuan organisasi yang telah menganut ISO 9001: 2000 sebagai standar mutu layanannya. Kompetensi jabatan staf P2PNFI mencakup dua komponen dasar, yaitu kompetensi utama dan kompetensi pendukung serta komponen pendukung yang meliputi kemampuan komunikasi dan pemanfaatan teknologi informasi.

\section{Tipe Ukuran Kinerja}

Tipe pengukuran kinerja berdasarkan lingkup ukuran oleh Amstrong dan Baron (1998: 275) dikategorikan dalam tiga tipe, yaitu (a) ukuran individual, (b) ukuran tim, dan (c) ukuran organisasional. Setiap tipe ukuran kinerja akan diuraikan dalam bahasan berikut ini.

Ukuran kinerja bagi individu berhubungan dengan akuntabilitas dan ditetapkan dalam kriteria kuantitas, kualitas, produktivitas, ketepatan waktu, dan efektivitas biaya. Ukuran kinerja individual sangat bervariasi menurut pekerjaan dan tanggung jawabnya. Ukuran-ukuran kinerja individu tersebut dapat diuraikan sebagai berikut (a) kuantitas, dinyatakan dalam bentuk jumlah output, atau persentase antara output aktual dengan output yang menjadi target, (b) kualitas, dinyatakan dalam bentuk pengawasan yang bervariasi di luar batas, jumlah keluhan yang masih dalam batas dapat diper-timbangkan untuk ditoleransi, (c) produktivitas, diukur sebagai output perpekerja, (d) ketepatan waktu, dinyatakan dalam bentuk pencapaian batas waktu pengiriman, jumlah unit yang dapat diselesaikan tepat waktu, (e) pengawasan biaya, sebagai biaya perunit produksi dan variasi upah buruh langsung/ tidak langsung.

Tujuan dari melakukan ukuran kinerja menurut Habour (1997: 9) adalah untuk menentukan : "base- line performance measures, trending performance measures, control performance measures, diagnostic performance measures, and planning performance measures."

Penelitian ini akan mengukur kinerja responden secara tidak langsung yaitu dengan menggunakan alat berupa kuesioner yang diberikan kepada responden dan responden akan memberi penilaian kepada kinerjanya masing-masing, secara keseluruhan menurut ukuran sebagai individu untuk kinerja yang berkaitan dengan tugas struktural dan ukuran kinerja tim yang berkaitan dengan satuan tugas pamong pada kelompok-kelompok kerja di P2PNFI.

Ukuran iklim kerja secara kualitatif dan kuantitatif oleh Dharma S., (2010:88-90) disebut dengan standar kinerja kualitatif dan kuantitatif. Standar kinerja tersebut oleh Anwar (2005: 18-19) dirumuskan dalam pernyataan-pernyataan sebagai berikut.

Standar kinerja kualitatif adalah sebagai berikut: a. ketepatan kerja dan kualitas pekerjaan; b. tingkat kemampuan dalam bekerja; c. kemampuan dalam menganalisis data/informasi, kemampuan/kegagalan menggunakan mesin/peralatan; dan d.kemampuan mengevaluasi (keluhan/keberatan konsumen).

Standar kinerja kuantitatif adalah sebagai berikut: a. proses kerja dan kondisi pekerjaan; b. waktu yang dipergunakan atau lamanya melaksanakan pekerjaan; c. jumlah kesalahan dalam melaksanakan pekerjaan; dan d.jumlah dan jenis pemberian pelayanan dalam bekerja.

Berdasarkan uraian kinerja, ukuran kinerja serta standar kinerja yang dikemukakan oleh para ahli di atas, kinerja yang akan diteliti dalam penelitian ini akan dikelompokkan dalam dua ukuran yaitu: 1 . kualitas dan 2. kuantitas. Ukuran kinerja berdasarkan kualitasnya dapat diidenfitifikasi sebagai berikut :

a. Kualitas kerja yang mencakup : ketepatan cara kerja, ketepatan waktu, layanan yang bermutu

b. Kemampuan komunikasi : kemampuan komunikasi yang baik dengan sesama staf (internal) baik vertikal maupun horizontal, kemampuan komunikasi yang baik dengan pelanggan (eksternal).

c. Keterlibatan dalam proses kerja meliputi : tanggung jawab, kerjasama, partisipasi dan kontribusi.

d. Kemampuan dalam melakukan pekerjaan meliputi : konsistensi, dan efektivitas dalam bekerja

e. Pengelolaan sumber daya, yaitu: efektivitas penggunaan sumber-sumber organisasi.

Kinerja berdasarkan ukuran kuantitasnya dapat diidentifikasi sebagai berikut :

a. Proses kerja, meliputi : kehadiran, absensi.

b. Kemampuan melaksanakan pekerjaan, meiputi 
: kecepatan penyelesaian pekerjaan, kecepatan menyelesaikan masalah, jumlah masalah yang dapat diselesaikan, kemampuan dalam mengurangi jumlah kesalahan bekerja,

c. Perluasan pekerjaan, meliputi : kemampuan menangani sejumlah pekerjaan diluar tugas pokok, kemampuan mengangani pekerjaan sesuai dengan tuntutan pelanggan.

d. Output pekerjaan, meliputi : Volume pekerjaan yang dihasilkan, banyaknya pelanggan yang dapat direkrut.

e. Penggunaan biaya, meliputi : efisiensi pengelolaan pembiayaan, menciptakan sumber-sumber.

Cara menilai atau mengukur kinerja individu dalam organisasi, yaitu dengan menerapkan salah satu diantara model penilaian kinerja sebagaimana yang dikemukakan oleh Durcker P, dan McGregor D, dikutip oleh Dharma S., (2010:200-215) yaitu: a. penilaian atas diri sendiri, b. penilaian oleh bawahan, c. penilaian oleh rekan sejawat, d. penilaian oleh multi assesment, e.umpan balik dan konseling dalam penilaian kinerja

Penilaian atas diri sendiri merupakan penilaian yang memungkinkan dapat dilakukan setiap individu untuk mengetahui tingkat kinerja yang dilakukan apakah dapat berjalan secara efektif dan efisien, sehingga menghasilkan kinerja yang produktif dan tumbuhnya rasa kepuasan dalam bekerja, baik untuk memenuhi standar mutu layanan terhadap pelanggan ataupun kepentingan kelembagaan dalam meningkatkan citra lembaga atau organisasi layanan yang profesional. Penelitian ini akan menggunakan penilaian kinerja atas diri sendiri pada individu atau sekelompok orang yang ada dalam organisasi khususnya P2PNFI, sasaran penilaian yang berkait dengan tugas pokok dan fungsi adalah seluruh personal yang ada di jajaran P2PNFI. Penentuan seluruh personil tersebut dilandaskan atas tugas dan tanggungjawab pekerjaan yang diemban oleh masing-masing individu dalam mencapai tujuan organisasi.

Penerapan standar kerja berdasarkan ISO
9001:2000 merupakan suatu perubahan dalam manajemen kerja lembaga berupa layanan yang terstandar kepada pelanggannya. Proses penerapan ISO 9001:2000 didasarkan atas delapan prinsip yaitu : Prinsip 1 : Fokus Pelanggan, Prinsip 2 : Kepemimpinan, Prinsip 3 : Keterlibatan Orang, Prinsip 4 : Pendekatan Proses, Prinsip 5 : Pendekatan Sistem Terhadap Manajemen, Prinsip 6 : Peningkatan Terus Menerus, Prinsip 7 : Pendekatan Faktual Dalam Pembuatan Keputusan, Prinsip 8 : Hubungan Pemasok Yang Saling Menguntungkan. Prinsip 1 (satu) sampai prinsip 6 (enam) bagi lembaga yang baru menerapkan dalam pelaksanaannya memerlukan suatu organisasi pembelajar. Agar proses penerapan ISO 9001: 2000 dapat berjalan dengan baik maka lembaga P2PNFI dan seluruh staff termasuk pamong belajar sebagai pihak yang terkait langsung dengan pelanggan harus melakukan organisasi pembelajar. Organisasi pembelajar dalam lembaga P2PNFI dicirikan dengan adanya 5 (lima) disiplin pembelajaran yaitu: 1) kemampuan pribadi (personal mastery), (2) berbagi visi (share vision), (3) model mental (mental model) , (4) berfikir sistemik (system thinking) dan (5) belajar bersama (team learning). Organisasi pembelajar merupakan suatu triger (pendorong) dalam pencapaian kinerja berdasarkan ISO 9001:2000. Agar kerangka berfikir dalam penelitian ini dapat dimengerti lebih jelas lagi maka dapat digambarkan alur berfikirnya sebagai berikut :

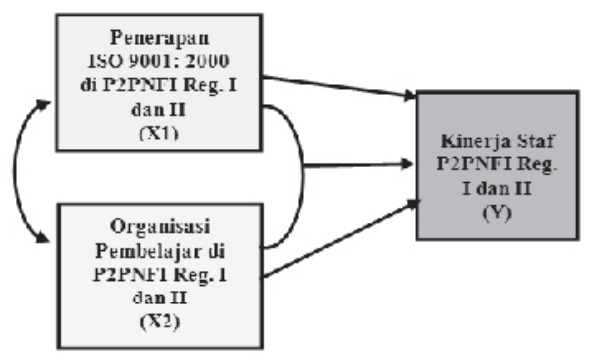

Gambar 1. Skema Kerangka Berfikir Penelitian

\section{METODOLOGI PENELITIAN}

Metode penelitian yang digunakan dalam penelitian ini adalah metode metode expost facto. Furchan (1982: 50) mengatakan penelitian expost facto ialah suatu penyelidikan ilmiah yang mengamati variabel terikat sebagai hasil dari satu atau lebih variabel bebas, di mana variabel bebas tersebut tidak dapat dimanipulasi oleh peneliti. Pendekatan yang digunakan dalam penelitian ini adalah pendekatan korelasional. Penggunaan teknik korelasional adalah untuk melihat hubungan satu atau lebih variabel bebas (independen) dengan satu atau lebih variabel terikat (dependen).

\section{Tujuan Penelitian}

Secara umum penelitian ini bertujuan untuk mengetahui hubungan penerapan ISO 9001:2000 dengan organisasi pembelajar dan kinerja staff di lembaga P2PNFI Regional I Jayagiri dan P2PNFI Regional II Semarang. Adapun tujuan khususnya ada-lah : 1. Mengetahui hubungan variabel ISO 9001:2000 
terhadap organisasi pembelajar di lembaga P2PNFI Regional I Jayagiri dan P2PNFI regional II Semarang, 2. Mengetahui hubungan antara organisasi pembelajar dengan kinerja staff di lembaga P2PNFI Regional I Jayagiri dan P2PNFI Regional II Semarang, 3. Mengetahui kontribusi variabel ISO 9001:2000 terhadap organisasi pembelajar staff di lembaga P2PNFI Regional I Jayagiri dan P2PNFI Regional II Semarang, 4. Mengetahui kontribusi variabel organisasi pembelajar terhadap kinerja staf di lembaga P2PNFI Regional I Jayagiri dan P2PNFI Regional II Semarang, 5. Mengetahui kontribusi variabel ISO 9001:2000 dan organisasi pembelajar terhadap kinerja staf di lembaga P2PNFI Regional I Jayagiri dan P2PNFI Regional II Semarang

\section{Lokasi dan Populasi Penelitian.}

Lokasi yang dijadikan tempat penelitian adalah Lembaga P2PNFI Regional I Jayagiri dan P2PNFI Regional II Semarang. Kedua lembaga ini dijadikan lokasi penelitian, didasarkan pada berbagai pertimbangan, yaitu:

1. Berdasarkan hasil studi pendahuluan dari beberapa lembaga BPPNFI, P2PNFI Regional I Jayagiri dan Regional II Semarang telah menerapkan standar layanan berdasarkan ISO 9001:2000 dan telah mendapat sertifikat ISO 9001:2000.

2. Penerapan ISO 9001: 2000 mensyaratkan adanya delapan prinsip yang menjadi dasar dalam pelaksanaan kinerjanya. Hal ini menyebabkan seluruh staff harus melakukan pembelajaran secara terus menerus agar dapat menerapkan layanan berdasarkan ISO 9001:2000.

3. Adanya semangat terjadinya organisasi organisasi pembelajar di lembaga tersebut.

4. Adanya kinerja baru yang berlandaskan semangat ISO 9001:2000 dan organisasi pembelajar.

Populasi menurut Sugiyono (2009: 389) diartikan sebagai "wilayah generalisasi yang terdiri atas: obyek/subyek yang mempunyai kualitas dan karakteristik tertentu yang ditetapkan oleh peneliti untuk dipelajari dan kemudian ditarik kesimpulannya. McMillan dan Schumacher (2001:169) mendefinisikan populasi sebagai: "A group of elements or cases, whether individuals, objects, or events, that conform to specific criteria and to which we intend to generalize the results of the research". Berdasarkan defenisi-definisi tersebut dapat disimpulkan populasi bukan hanya orang, namun kadang-kadang juga obyek, kejadian, yang memiliki sejumlah karakteristik/sifat yang dimiliki oleh subyek atau obyek penelitian untuk diteliti dan disimpulkan sebagai suatu hasil penelitian. Populasi adalah kelompok besar dan wilayah yang menjadi lingkup penelitian. Populasi dalam penelitian ini adalah seluruh staff dan pamong di P2PNFI Regional I dan II.

Seluruh staf dan tenaga fungsional yang sesuai dengan ciri-ciri di atas akan dijadikan responden dalam penelitian ini. Jumlah populasi penelitian di P2PNFI Regional I Jayagiri berjumlah 90 orang, sedang populasi penelitian di P2PNFI Regional II Semarang berjumlah 84 orang.

\section{Defenisi Operasional dan Variabel Penelitian.}

Sebagai acuan mengenai beberapa konsep yang digunakan dalam penelitian ini, dijelaskan beberapa definisi operasional, sebagai berikut :

1. Standar ISO 9001: 2000.

Standar ISO 9001: 2000 untuk sistem manajemen kualitas (Quality Management System, QMS) adalah: "struktur organisasi, tanggungjawab, prosedur-prosedur, proses-proses, dan sumber-sumber daya untuk penerapan manajemen kualitas". Dalam penelitian ini penerapan Standar ISO 9001:2000 dimaksudkan sebagai standar Sistem manajemen kualitas yang dilaksanakan berdasarkan delapan prinsip yaitu: 1. Fokus Pelanggan, 2. Kepemimpinan, 3. Keterlibatan Orang, 4. Pendekatan Proses, 5. Pendekatan Sistem Terhadap Manajemen, 6. Peningkatan Terus Menerus, 7. Pendekatan Faktual Dalam Pembuatan Keputusan, 8. Hubungan Pemasok Yang Saling Menguntungkan

2. Organisasi pembelajar.

Organisasi pembelajar adalah suatu keadaan, usaha, pembelajaran yang dilakukan oleh suatu organisasi atau lembaga untuk meningkatkan kemampuan orang-orangnya yang dilakukan secara terus menerus, dengan cara berfikir yang baru dan luas, memiliki kemampuan menilai diri, memiliki mental yang baik dan tangguh, mampu untuk berbagi visi, serta mampu bekerjasama sebagai suatu tim, untuk memenuhi tuntutan perubahan agar dapat mencapai tujuan yang ingin dicapai yaitu menjadi sebuah lembaga yang berkinerja sesuai standar ISO 9001:2000 yang menjadi tujuan bersama.

Dalam penelitian ini organisasi pembelajar ditunjukkan dengan adanya lima variabel sebagai disiplin pembelajaran yaitu : 1. Disiplin kemampuan personal (personal mastery), 2. Disiplin berbagi visi (share Vision), 3. Disiplin berfikir sistemik (system thinking), 4. Disiplin model mental (mental model) dan 5. Disiplin pembelajaran tim (team learning).

\section{Kinerja.}

Kinerja adalah suatu hasil atau kondisi (prestasi) yang diperoleh sebagai hasil dari suatu tindakan yang dilakukan oleh seseorang atau sekelompok orang 
atas tugas-tugas yang menjadi tanggung jawabnya sesuai dengan tujuan yang ingin dicapai yang telah ditetapkan sebelumnya.

Dalam penelitian ini kinerja yang akan diteliti dalam penelitian ini diteliti dikelompokkan dalam dua ukuran, yaitu: 1. Kualitas dan 2. Kuantitas. Ukuran kinerja berdasarkan kualitasnya dapat diidenfitifikasi sebagai berikut :

a. Kualitas kerja yang mencakup : ketepatan cara kerja, ketepatan waktu, layanan yang bermutu

b. Kemampuan komunikasi : kemampuan komunikasi yang baik dengan sesama staf (internal) baik vertikal maupun horizontal, kemampuan komunikasi yang baik dengan pelanggan (eksternal).

c. Keterlibatan dalam proses kerja meliputi : tanggung jawab, kerjasama, partisipasi dan kontribusi.

d. Kemampuan dalam melakukan pekerjaan meliputi : konsistensi, dan efektivitas dalam bekerja

e. Pengelolaan sumber daya, yaitu: efektivitas penggunaan sumber-sumber organisasi.

Kinerja berdasarkan ukuran kuantitasnya dapat diidentifikasi sebagai berikut :

a. Proses kerja, meliputi : kehadiran, absensi.

b. Kemampuan melaksanakan pekerjaan, meiputi : kecepatan penyelesaian pekerjaan, kecepatan menyelesaikan masalah, jumlah masalah yang dapat diselesaikan, kemampuan dalam mengurangi jumlah kesalahan bekerja,

c. Perluasan pekerjaan, meliputi : kemampuan menangani sejumlah pekerjaan diluar tugas pokok, kemampuan mengangani pekerjaan sesuai dengan tuntutan pelanggan.

d. Output pekerjaan, meliputi : banyaknya jumlah atau hasil kerja.

Variabel dalam penelitian ini terdiri atas tiga variabel yang terdiri dari dua variabel bebas dan satu variabel terikat. Variabel-variabel tersebut adalah sebagai berikut : Variabel bebas, yakni : a. Penerapan ISO 9001: 2000 yang disimbolkan dengan (X1); b. Organisasi pembelajar yang disimbolkan dengan (X2); Variable terikat adalah kinerja staff yang disimbolkan dengan (Y).

\section{Teknik Analisa Data}

Teknik analisa data yang akan digunakan dalam penelitian ini adalah analisis korelasional. Analisis korelasi digunakan untuk mencari arah dan kuatnya hubungan antara dua variabel atau lebih, baik hubungan yang bersifat simetris, kausal dan reciprocal. Kuatnya hubungan antar variabel yang dihasilkan dari analisis korelasi dapat diketahui berdasarkan besar kecilnya koefisien korelasi yang harganya antara minus satu (-1) sd plus satu (+ (1). Koefisien korelasi yang mendekati minus 1 atau plus 1 , berarti hubungan variabel tersebut sempurna negatif atau sempurna positif. Bila koefisien korelasi ( $r$ ) tinggi, pada umumnya koefisien regresi (b) juga tinggi, sehingga daya prediktifnya akan tinggi. Bila koefieisen korelasi minus (-), maka pada umumnya koefisien regresi juga minus (-) dan sebaliknya. Data yang akan dianalisis menggunakan teknik korelasional ini adalah data variabel X1 (ISO 9001:2000) dengan Variabel Y (Kinerja staf), variabel X2 (Organisasi Pembelajar) dengan Variabel Y (Kinerja staf). Untuk melihat korelasi antar kedua variabel akan digunakan rumus Product Moment ( $r$ ) dari Pearson, dengan rumus sbb:

$$
r_{x y}=\frac{N \cdot \sum X Y-\left(\sum X\right)(\Sigma Y)}{\sqrt{\left[N \cdot \sum X^{2}-(\Sigma X)^{2}\right]\left[N \cdot \sum Y^{2}-(\Sigma Y)^{2}\right]}}
$$

Pengujian signifikansi koefisien korelasi digunakan uji t (Sugiyono, 2007: 230) dengan rumus sebagai berikut :

$$
t=\frac{r \sqrt{ }-2}{\sqrt{1-r^{2}}}
$$

Selanjutnya dilakukan analisis korelasi ganda terhadap variabel $\mathrm{X}_{1}$ dan $\mathrm{X}_{2}$ dengan variabel $\mathrm{Y}$. Untuk melihat korelasi antar ketiga variabel rumus yang digunakan (Sugiyono, 2007: 233) adalah sebagai berikut:

$$
R_{v \times 1 \times 2}=\sqrt{\frac{r_{y \times 1}{ }^{2}+r_{y \times 2}{ }^{2}-2 r_{y x 1} r_{y \times 2} r_{x 1 \times 2}}{1-r_{x 1 \times 2}}}
$$

Pengujian signifikansi terhadap koefisien korelasi ganda digunakan uji $F$ (Sugiyono, 2007: 235) dengan rumus sebagai berikut :

$$
F h=\frac{R^{2} / k}{\left(1-R^{2}\right) /(N-k-1)}
$$

Selanjutnya dilakukan analisis korelasi ganda terhadap variabel $X_{1}$ dan $X_{2}$ serta variabel $Y$. Untuk melihat korelasi antar ketiga variabel rumus yang digunakan (Sugiyono, 2007: 236) sebagai berikut:

$$
R_{\mathrm{v} \times 1 \times 2}=\frac{r_{y \times 1}-r_{y \times 2} \cdot r_{x 1 \times 2}}{\sqrt{1-r^{2}{ }^{2} \times 2 \times 2}-\sqrt{1-r^{2}}}
$$

Pengujian signifikansi koefisien korelasi Parsil digunakan uji t (Sugiyono, 2007:237) dengan rumus sebagai berikut :

$$
t=\frac{r_{p} \sqrt{ }-2-1}{\sqrt{ } 1-r_{p}^{2}}
$$




\section{HASIL PENELITIAN}

Hasil penelitian menunjukkan bahwa terdapat : (1) adanya peningkatan kinerja staf, (2) adanya hubungan antara penerapan ISO 9001:2000 dengan kinerja staf, (3) adanya hubungan antara organisasi pembelajar dengan kinerja staf dan (4) adanya hubungan antara penerapan ISO 9001:2000 dan organisasi pembelajar dengan kinerja staf di kedua kelompok penelitian.

Hasil penelitian di P2PNFI Regional I Jayagiri: penerapan ISO 9001:2000 dengan kinerja staf di P2PNFI Regional I Jayagiri sebesar 0,860; organisasi pembelajar dengan kinerja staf sebesar 0,900; penerapan ISO 9001:2000 dengan organisasi pembelajar sebesar 0,981 serta penerapan ISO 9001:2000 dan organisasi pembelajar dengan kinerja staf sebesar 0,907. Kategori korelasi termasuk dalam pengkategorian korelasi yang sangat baik dengan uji signifikansi F hitung sebesar 203,55 > F tab 3,11.

Hasil penelitian di P2PNFI Regional II Semarang: penerapan ISO 9001:2000 dengan kinerja staf di P2PNFI Regional I Jayagiri sebesar 0,840; organisasi pembelajar dengan kinerja staf sebesar 0,895; penerapan ISO 9001:2000 dengan organisasi pembelajar sebesar 0,947 serta penerapan ISO 9001:2000 dan organisasi pembelajar dengan kinerja staf sebesar 0,895. Kategori korelasi termasuk dalam pengkategorian korelasi yang sangat baik dengan uji signifikansi $\mathrm{F}$ hitung sebesar 163,46 > F tabel 3,11.

\section{KESIMPULAN}

\section{Kesimpulan}

Kesimpulan yang dapat ditarik dalam penelitian berdasarkan hasil analisisa data pada Bab IV adalah sebagai berikut :

1. Korelasi antara penerapan ISO 9001:2000 dengan kinerja staff di lembaga P2PNFI Reg. I Jayagiri dan di P2PNFI Reg. II Semarang secara keseluruhan terdapat korelasi yang sangat kuat

2. Korelasi antara organisasi pembelajar dengan kinerja kinerja staff di Lembaga P2PNFI Regional I Jayagiri dan di P2PNFI Regional II Semarang secara keseluruhan terdapat korelasi yang sangat kuat

3. Terdapat korelasi yang sangat kuat antara penerapan ISO 9001:2000 dan organisasi pembelajar dengan kinerja staf di Lembaga P2PNFI Regional I Jayagiri dan di P2PNFI Regional II Semarang.

4. Tingkat penerapan ISO 9001:2000, organisasi pembelajar dan kinerja Staf struktural di Lembaga P2PNFI Regional I Jayagiri lebih baik dari pada pamong belajar.

5. Tingkat penerapan ISO 9001:2000, organisasi pembelajar dan kinerja Staf dan pamong belajar di lembaga P2PNFI Regional II Semarang sama baiknya

6. Terdapat peningkatan kinerja staf yang signifikan setelah penerapan ISO 9001:2000 di Lembaga P2PNFI Regional I Jayagiri dan di Lembaga P2PNFI Regional II Semarang.

7. Penerapan ISO $9001: 2000$ dalam manajemen kerja tanpa diiringi dengan organisasi pembelajar yang baik dari seluruh staf akan memberikan dampak buruk terhadap kinerja staf di Lembaga P2PNFI Regional I Jayagiri maupun di P2PNFI Regional II
Semarang.

Implikasi:

Dari beberapa kesimpulan diatas, implikasinya adalah : (1) Pimpinan lembaga P2PNFI Regional I Jayagiri perlu memfasilitasi organisasi pembelajar staf dan pamong belajar agar dapat menerapkan sistem kerja berdasarkan ISO 9001:2000, (2) Pimpinan lembaga P2PNFI Regional I Jayagiri dan P2PNFI Regional II Semarang perlu menggiatkan diskusi-diskusi dengan seluruh staf dan pamong belajar, (3) Pimpinan lembaga P2PNFI Regional I Jayagiri dan P2PNFI Regional II Semarang perlu mengadakan kegiatan seminar yang berkenaan dengan manfaat ISO dan organisasi pembelajar untuk meningkatkan kinerja staf dan pamong belajar.

Saran

Saran yang perlu dijadikan bahan pertimbangan dari hasil penelitian ini adalah :

1. Secara Praktis

a. Pimpinan Lembaga P2PNFI Regional I Jayagiri dan P2PNFI Regional II Semarang agar dalam membuat kebijakannya agar memperhatikan aspek: (1) tingkat kesiapan, (2) persiapan, (3) pelatihan, (4) menyediakan sarpras pendukung, (5) menyediakan waktu untuk berdiskusi.

b. Staf agar: (1) mendukung kebijakan, (2) mengikuti pelatihan dengan sungguh-sungguh, (3) bersedia untuk diskusi.

\section{Secara Akademis}

Para peneliti lain melanjutkan penelitian tentang keterkaitan penerapan ISO 9001:2000 dan organisasi pembelajar dengan kinerja staf dengan variabel-variabel lain untuk memperluas pengetahuan, perbaikan dan peningkatan mutu layanan Lembaga PNF. 


\section{DAFTAR PUSTAKA}

Burgoyne. (1994), Personnel Management Plus, Centre for The Study of Management Learning, University of Lancaster.

Candy, P. \& Crebert, R.G. (1991). Lifelong learning: An enduring mandate for higher education. Higher Education Research and Development 10 (1), 3-15.

De Cenzo and Robbins. (1999). Human Resource Management, New York : John Wiley Inc.

Dharma S., (2010). Manajemen Kinerja Falsafah Teori dan Penerapannya, Yogjakarta: Pustaka Pelajar.

Furchan, Arief (1982). Pengantar Penelitian Dalam Pendidikan, Surabaya: Usaha Nasional.

Gaspersz, Vincent. 1997. Manajemen Kualitas: Penerapan Konsep-Konsep Kualitas Dalam Bisnis Total. Jakarta: Yayasan Indonesia Emas dan PT Gramedia Pustaka Utama.

Gaspersz, Vincent, (2006). ISO 9001:2000 And Continual Quality Improvement, Jakarta : PT Gramedia Pustaka Utama.

Jarvis, Peter John Holford, and Colin Griffin. (1998). The theory and Practice of Learning, London, Kogan Page.

Kamil, M., (2007). Model Pelatihan Pendidikan Luar Sekolah (Konsep dan Aplikasi), Bandung: Dewa Ruci.

Knapper Christopher K. \& Cropley Arthur J., (2000), Lifelong Learning in Higher Education, London, Kogan Page.

Longworth, Norman and W. Keith Davies. (1996). Lifelong Learning, New vision, new implication, new roles for people, organizations, nations and communities in the 21 st century. London : Kogan Page.

Longworth, Norman and W. Keith Davies. (2003), Lifelong Learning in Action, London, Kogan Page.

Luthans. F. (2007). Organizational Behavior. New York USA. McGraw-Hill International Edition. $11^{\text {th }}$ Edition.

Marquardt J. Michael. \& Angus Reynolds. (1994). The Global Learning Organization. New York: Irwin. Inc

Moeheriono. (2009). Pengukuran Kinerja Berbasis Kompetensi. Bogor : Ghalia Indonesia.

Noe, R.A., Hollenbeck, Gerhart, B., Wright, P.M.
(2000) Human Resource Management, Gaining a Competitive Advantage. $3^{\text {rd }} \mathrm{Ed}$. New York: McGraw-Hill Companies,Inc.

Senge, Peter M. (1990). The Fifth Discipline: the Art and Practice of the Learning Organization. New York: Doubleday.

Senge, Peter M, et al. Alih Bahasa Hari Suminto. (1995) "Buku Pegangan Disiplin Kelima" Strategi dan alat-alat, untuk membangun organisasi pembelajaran. Jakarta: Penerbit Interaksara

Senge. Peter M. Alih Bahasa Nunuk Adiarni. (1996). "Disiplin Kelima" Seni dan Praktek dari Organisasi Pembelajaran. Jakarta: Penerbit Binarupa Aksara.

Smith J., Spurling A., (1999). Lifelong Learning Riding The Tiger, NewYork: The Lifelong Learning Foundation.

Sturnman, Michael C. (2001) Searching for the Inverted U-shaped Relationship Betwee Time and performance: Meta Analyses of the Experience / Performance, tenure/ Performance, and Age/ Performance Relationship. USA: Journal of Management.

Sudjana. (1985). Metode Statistik. Bandung: Tarsito. Sugiyono. (2006). Metode Penelitian Kuantitatif-Kualitatif dan $R \& D$. Bandung : Alfabeta.

Sugiyono, (2009), Metode Penelitian Bisnis. Bandung : Alfabeta.

Surapranata, S. (2006). Analisis Validitas, Reliabilitas dan Interpretasi Hasil Tes. Bandung: Rosdakarya.

Tjakraatmadja, J.H. (2006). Knowledge Management Dalam Konteks Organisasi Pembelajar. Bandung: Sekolah Bisnis dan Manajemen - Institut Teknologi Bandung

Tricker, Ray. (2001) ISO 9001: 2000 For Small Businesses. Oxford: Butterworth-Heineman.

Trisnamansyah, S., (2007). Teori dan Perkembangan Implementasi Program Pendidikan Nonformal, Bandung: Sekolah Pasca Sarjana UPI, tidak diterbitkan.

Wibowo. 2009. Manajemen Kinerja. Jakarta. Rajawali Pers.

Wick, C W and Lean, L S (1995). Creating a Learning Organization: From ideas to action, Human Resource Management, Summer. 